\title{
Co-Teaching In Higher Education
}

Nancy Bacharach, (E-mail: nlbacharach@stcloudstate.edu), St. Cloud State University Teresa Washut Heck, (E-mail: twheck@ stcloudstate.edu), St. Cloud State University

\begin{abstract}
This paper will describe a project that includes 16 university level co-taught classes. Preparation of the faculty co-teaching along with results from the study will be shared.
\end{abstract}

\section{INTRODUCTION}

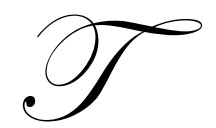

eachers at all levels of education are increasingly asked to draw on their collaborative skills to meet the needs of today's P-12 learners. It is not unusual for public school teachers to work together with grade or content level colleagues, special educators, and paraprofessionals to implement curriculum and to meet individual student needs. While implicit in most teacher preparation programs, many do not explicitly teach the skills necessary for successful collaboration. University based teacher preparation programs work to prepare teacher candidates to meet the needs of an increasingly diverse student population. Faculty within teacher preparation programs operate collaboratively to incorporate content, pedagogy, and clinical experiences, providing for their preservice candidates a strong foundation of theory and practice in education. According to York-Barr, Bacharach, Salk, Frank, \& Beniek (2004) and Wenzlaff, Berak, Wieseman, Monroe-Baillargeon, Bacharach, \& Bradfield-Kreider (2002), co-teaching university courses is one way to effectively model and develop the collaborative skills of teacher candidates.

Co-teaching has many meanings and is implemented in numerous ways. Cook and Friend (1995, p. 2) define co-teaching as "two or more professionals delivering substantive instruction to a diverse, or blended group of students in a single physical space." Wenzlaff, et. al. (2002, p. 14) agree that co-teaching is "two or more individuals who come together in a collaborative relationship for the purpose of shared work...for the outcome of achieving what none could have done alone." For the purposes of this program, co-teaching has been defined as "two teachers working together with groups of students and sharing the planning, organization, delivery and assessment of instruction, as well as the physical space." (Bacharach, Heck, \& Dank, 2003).

Cook and Friend (1995) initially presented co-teaching as a viable solution to special and general educators teaching together in mainstream classrooms. The use of co-teaching between general and special educators in PreK12 settings has been strongly advocated as a way to meet the learning needs of students who qualify for special educational services (Bauwens \& Hourcade, 1995; Vaughn, Schumm, \& Arguelles, 1997; Platt, Walker-Knight, Lee, \& Hewitt, 2001). The extent of co-teaching at the university level has been much less prevalent and very loosely studied. At some higher education institutions co-taught courses are simply a division of duties or roles, with faculty teaching an every other class schedule or a certain number of weeks as course credit load is merely divided. Some programs have created a common core of classes required of all education majors (Blanton \& Nowacek, 1995) while others have created an entire unified special/general teacher preparation program (Barbus, Tuttle, \& Prime, 1995; Meyers \& Biklen, 1992). York, Bacharach, Salk, Frank \& Beniek in 2004 studied six pairs of general/special education faculty who co-taught teacher preparation courses as a part of an integrated general/special teacher education program. They suggest that “...team teaching experiences could improve teacher education by offering preservice students the opportunity to learn from faculty with varied backgrounds and to experience a form of collaboration that strikes at the core of instructional practice". (p. 91).

Research indicates an increasing use of co-teaching at the university level in preparing dually licensed general and special education teachers. Notably absent from the literature, however, is the study of co-teaching outside of the special education domain. By providing opportunities for teacher candidates to participate in courses co-taught by either two university faculty members or by a university faculty and a practicing P-12 educator, 
program initiators have found a way to immerse teacher candidates in a collaborative environment. Using current research as a base, this paper will focus on the implementation of co-teaching at the university level in general teacher preparation courses.

\section{METHODOLOGY}

As part of a larger co-teaching initiative funded by a federal grant, one mid-sized Midwestern university has incorporated co-teaching into selected preservice education courses. Three university courses in teacher education are co-taught each semester. An application and rubric for scoring are made available to faculty interested in applying. Applicants are rated on their rationale for wanting to co-teach, their plan for building the co-teaching relationship, the expected number of students enrolled and the professionalism of the application.

Over five semesters spanning 2004-2006, sixteen university courses were co-taught. Six of these courses involved a university faculty member and a public school teacher. The remaining ten courses had two university faculty members co-teaching. Table 1 shows the courses and when they were taught

Table 1. Co-teaching courses and faculty

\begin{tabular}{|c|l|c|}
\hline Pair Number & \multicolumn{1}{|c|}{ Course Title } & Semester \\
\hline$\# 1$ & Human Relations for Teachers & Spring 04 \\
\hline$\# 2$ & Teaching Methods in Special Education 04 \\
\hline$\# 3$ & Emotional Behavior Disorders & Spring 04 \\
\hline$\# 4$ & Methods in Early Education & Fall 04 \\
\hline$\# 5$ & Teaching Methods in Special Education & Spring 05 \\
\hline$\# 6$ & $\begin{array}{l}\text { Children's Literature in PreK-Grade 3 } \\
\text { Classrooms }\end{array}$ & Spring 05 \\
\hline$\# 7$ & Teaching young adult literature & Fall 05 \\
\hline$\# 8$ & $\begin{array}{l}\text { Teaching English as a Second } \\
\text { Language: Theory and Methods }\end{array}$ & Fall 05 \\
\hline$\# 9$ & Technology Education & Fall 05 \\
\hline$\# 10$ & $\begin{array}{l}\text { Methods and Materials of Elementary } \\
\text { \& secondary health education }\end{array}$ \\
\hline$\# 11$ & $\begin{array}{l}\text { Children's Literature in PreK-Grade 3 } \\
\text { Classrooms }\end{array}$ & Spring 06 \\
\hline$\# 12$ & Foundations of Education & Spring 06 \\
\hline$\# 13$ & $\begin{array}{l}\text { Professional Subject Matter for } \\
\text { Secondary School Math }\end{array}$ & Spring 06 \\
\hline$\# 14$ & Concepts and Theories in History & $\begin{array}{l}\text { Spring 06 } \\
\text { Math/Science/Social Studies }\end{array}$ \\
\hline$\# 15$ & $\begin{array}{l}\text { Teacher English as a Second Language: } \\
\text { Reading and Writing }\end{array}$ & Spring 06 \\
\hline$\# 16$ & \begin{tabular}{l} 
\\
\hline
\end{tabular} & \\
\hline
\end{tabular}

At the beginning of the semester, the teams attended a four-hour workshop on co-teaching. The workshop taught the various co-teaching models suggested by Friend and Cook (1995) and modified by the authors (See Table 2). After each strategy was described, examples for using the approach were presented and participants were asked to discuss how they might apply the strategy in their co-taught course. Feedback from students in the first and subsequent semesters helped to reshape and strengthen the workshop each time it was presented.

The second phase of the workshop focused on communication and building interpersonal skills. Participants took the Gregorc Style Delineator (Gregorc, 2004) to determine their working style. Each person then shared their results with their co-teaching partner and discussed the results and their implications on how they might 
work together as a team. Specific questions were then used to facilitate higher level thinking and discussions about participants' readiness to share and commit to the co-teaching relationship. These thought-provoking questions led to rich discussion about how to work productively as a team. Participants discussed how to share instructional time and space. They established a relationship that allowed and encouraged them to engage in constructive problem solving. These skills are essential in the success of any co-teaching partnership.

Table 2. Co-teaching strategies

\begin{tabular}{|c|c|}
\hline Strategy & Definition/Application \\
\hline One Teach, One Observe & $\begin{array}{l}\text { When using one teach, one observe, one teacher has primary instructional } \\
\text { responsibility while the other gathers specific observational information on } \\
\text { students or the (instructing) teacher. The key to this strategy is to focus the } \\
\text { observation - where the teacher doing the observation is observing specific } \\
\text { behaviors. }\end{array}$ \\
\hline One Teach, One Drift & $\begin{array}{l}\text { One teach, one drift is an extension of one teach, one observe. One teacher has } \\
\text { primary instructional responsibility while the other assists students' with their } \\
\text { work, monitors behaviors, or corrects assignments, often lending a voice to } \\
\text { students or groups who would hesitate to participate. }\end{array}$ \\
\hline Station Teaching & $\begin{array}{l}\text { For station teaching the co-teaching pair divide the instructional content into } \\
\text { parts. Each teacher instructs one of the groups. Groups then rotate or spend a } \\
\text { designated amount of time at each station. Often an independent station will be } \\
\text { used along with the teacher led stations. }\end{array}$ \\
\hline Parallel Teaching & $\begin{array}{l}\text { In this approach, each teacher instructs half the students. The two teachers are } \\
\text { addressing the same instructional material. The greatest benefit to this approach } \\
\text { is the reduction of student to teacher ratio. }\end{array}$ \\
\hline Supplemental Teaching & $\begin{array}{l}\text { This strategy allows one teacher to work with students at their expected grade } \\
\text { level, while the other teacher works with those students who need the } \\
\text { information and/or materials extended or remediated. }\end{array}$ \\
\hline Alternative (Differentiated) Teaching & $\begin{array}{l}\text { Alternative teaching strategies provide two different approaches to teaching the } \\
\text { same information. The learning outcome is the same for all students however } \\
\text { the avenue for getting there is different. }\end{array}$ \\
\hline Team Teaching & $\begin{array}{l}\text { Well planned, team taught lessons, exhibit an invisible flow of instruction with } \\
\text { no prescribed division of authority. Using a team teaching strategy, both } \\
\text { teachers are actively involved in the lesson. From a students' perspective, there } \\
\text { is no clearly defined leader - as both teachers share the instruction, are free to } \\
\text { interject information, and available to assist students and answer questions. }\end{array}$ \\
\hline
\end{tabular}

\section{Data Sources}

At semester end, students in each of the co-taught classrooms were asked to complete an evaluation about co-teaching. Students were asked their level of agreement (4= high agreement to $1=$ don't agree) about how much individual factors of co-teaching impacted their learning. Factors included such items as having two different perspectives, two distinct instructional styles, increased availability of instructors and the lower student/teacher ration. Additionally, students were asked if they thought they learned more in a co-taught class, if they thought other course should be co-taught, and if they would like to use co-teaching in their own classroom someday. The next part of the evaluation had students rate their instructors on a 4 point likert scale on their ability to work together. Room was provided at the end of the final evaluation for additional comments and feedback. Rather than having students directly return surveys to their professors, the survey was administered by a representative from the project.

In addition to seeking student feedback at semester end, co-teaching faculty were also asked a series of open ended questions regarding their experience. 


\section{RESULTS}

\section{Student Perspective - Benefits}

Results from the surveys ( $\mathrm{N}=372)$ were synthesized to incorporate both student rating of co-teaching factors as well as responses to open ended questions. The results from the question "How much do you agree that each of the following positively impacted your learning in this course" are shown in Table 3. Two factors, Instructors have two different knowledge bases on current topics and the Lower student/teacher ratio had the highest mean at 3.5. Students overwhelmingly identified having two different knowledge bases, hearing two different perspectives on topics and a diversity of experiences as a benefit to co-teaching.

I do like the fact of getting two different perspectives and that the time spent in class is always productive. -Teacher Candidate

I love having two perspectives to listen to. They complement each other and one keeps the other on track. -Teacher Candidate

Table 3. Student responses

\begin{tabular}{|l|c|}
\hline \multicolumn{1}{|c|}{ Positive Aspects of Co-Teaching } & Mean Rating \\
\hline Instructors have two different knowledge bases on course content & 3.5 \\
\hline Hearing two different perspectives from instructors & 3.4 \\
\hline The diversity of experiences shared by two instructors & 3.4 \\
\hline Experiencing two distinct instructional styles & 3.3 \\
\hline Having instructors build off each other & 3.4 \\
\hline Increased availability of instructors & 3.4 \\
\hline More variety in activities & 3.3 \\
\hline Lower student/teacher ratio & 3.5 \\
\hline
\end{tabular}

The other big benefit discussed by the students was having a lower student-to-teacher ratio. This was often expressed in the open-ended responses as an ability to break into smaller groups for work on projects or for more indepth discussions.

I was able to ask questions more often. -Teacher Candidate

Ifelt like with two teachers in the room it was easier to have my needs met. -Teacher Candidate

The next two benefits most frequently identified by students were: the increased availability of instructors and teachers building off each other.

I liked having two teachers because whenever you needed to get a hold of the teacher you had a good chance of talking to them because there was always someone else to try if the other one was unavailable. -Teacher Candidate

I enjoy the co-teaching used in this class. It helps me to be engaged in the topic when one person throws in a random opinion or experience. The two teachers really feed off of each other as well. -Teacher Candidate

All 8 of the items came in at 3.3 or higher indicating a high level of agreement with all of the statements

\section{Student Perspective - Drawbacks}

Four primary drawbacks were identified by students: confusion about who to go to, grading or homework concerns, inequitable division of time, and lack of organization. Each of these drawbacks is addressed below. 
1. Confusion about who to go to was often listed as an initial concern that diminished as the semester wore on. Focusing on this factor in the faculty workshop also helped to decrease the number of students listing this as a concern in later semesters of the program.

2. Grading or homework issues were identified as a concern by students. These comments ranged from feeling undue pressure having two people critique classroom presentations to feeling that the faculty graded differently and students were unsure of who was making final grading decisions.

3. Student comments regarding inequitable division of instructional time were generally centered on student preferences for one instructional style or personality over the other.

4. Lack of organization was cited as a drawback with higher frequency early in the project.

\section{Student Perspective - Co-Teaching Factors}

On the final evaluation, students were asked to rate four indicators of effective co-teaching (Villa, R., Thousand, J. \& Nevin, A., 2004) on a four point Likert scale. Each item was rated with 4=Almost Always and $1=$ Hardly ever. Results are as follows:

$\begin{array}{ll}\text { 1. Instructors model respect for one another } & 3.8\end{array}$

2. Transitions between instructors are well-coordinated 3.3

3. Instructors clearly and explicitly describe the co-teaching strategies they model $\quad 3.1$

4. Instructional time has been equitably shared 3.1

In addition, $89 \%$ of students answered 'yes' when asked if other teacher preparation courses should be cotaught and they indicated a high interest in co-teaching themselves some day $(85 \%)$. Of great importance was the fact that $74 \%$ of the students indicated they learned more in a co-taught class than they would have in a class that was not co-taught.

\section{Faculty Perspectives}

Faculty and classroom teachers who co-taught university classes were asked a series of open-ended questions following the co-teaching experience. The co-teaching faculty responding to the survey unanimously agreed that they would co-teach again.

I would co-teach again in a heartbeat! -co-teaching faculty they learned.

Co-teaching faculty reported that one of the biggest benefits of the co-teaching experience was how much

I would love to co-teach again. I learned so much in the process; planning, sharing, general information, and current studies/research. - co-teaching faculty

Respondents talked about learning content material and instructional techniques from their co-teaching partner. Many reflected on the fact that the most notable learning that occurred was reflection on their own practice. Co-teachers reported that the experience helped them to improve their teaching by providing insights into their own strengths, weaknesses, strategies, and styles.

After teaching 'solo' my whole career, I found consulting with a peer on all decisions (small and large), really forced me to be conscientious about all that I do and say. I also relearned the art of listening to another's perspective when it comes to making pedagogical decisions. In some ways, this experience felt like I was student teaching again. - co-teaching faculty

I also understand now, on a deeper level, the magnitude of the responsibility we have in preparing future teachers. Hearing another instructor expound upon things I deal with on a daily basis has opened my eyes. - co-teaching faculty 
Faculty respondents also discussed the vital role that co-planning plays in a successful co-teaching experience. While the time consuming nature of the planning was mentioned by nearly all respondents, the tremendous benefits of spending that time together seemed to over shadow the extra time required.

Co-teaching wouldn't work if the pair didn't plan and reflect together.”- co-teaching faculty

I think it was the most engaging and beneficial time that we spent together - - even more powerful than the teaching itself." co-teaching faculty

The biggest drawback was probably the time it took to communicate effectively between classes. I think that we got it down to a 'system', but still took extra time. - co-teaching faculty

It is extra work to plan at first, but it seems to get easier as you go through the semester. - co-teaching faculty

Faculty identified numerous benefits to students in co-taught settings, primarily the diverse viewpoints and instructional styles, more individualized attention, demonstration of collaboration, and modeling of professional relationships.

It's a bit of a cliché, but two minds are better than one. [My co-teacher] and I worked very well together, and we made all of our decisions in concert. We were a united front, and that translates to confidence in the classroom. We double-checked all assessments of student work with each other, and students could see us working in tandem. - coteaching faculty

Students get to see us collaborating and constructing and processing the course in a raw and first hand fashion.co-teaching faculty

As for drawbacks to students, the faculty identified moderate confusion over whom to go to regarding assignments or questions. Interestingly, there was also a strong concern for the ability of students to form relationships with co-teaching faculty.

In my estimation, the only drawback for students might be their inability to develop a solid rapport with one teacher. Given that we were a team, some students weren't sure of the protocol regarding which one of us they should talk to. - co-teaching faculty

Students who already knew the university faculty member from previous classes had a relationship with that person. Relationships with the new instructors had to be built. If the relationship with the known instructor had been strong, some students were reluctant to transfer trust to the new instructor. - co-teaching faculty

Finally, faculty were asked to provide words to describe their co-teaching experience. The responses are included in Table 4. As can be seen from the data, faculty perspectives about co-teaching were very positive.

Table 4. Co-teaching descriptors

\section{$\underline{\text { Co-Teaching Descriptors }}$}

$\begin{array}{lll}\text { Beneficial } & \text { Exploration } & \text { Positive } \\ \text { Collaborative } & \text { Fantastic } & \text { Renewing } \\ \text { Delightful } & \text { Fun } & \text { Respectful } \\ \text { Educational } & \text { Humbling } & \text { Revitalizing } \\ \text { Effort } & \text { Inspiring } & \text { Rewarding } \\ \text { Engaging (2) } & \text { Overwhelming (2) } & \text { Sparking } \\ \text { Enlightening } & \text { Planning } & \text { Thorough } \\ \text { Exhilarating } & & \end{array}$




\section{DISCUSSION}

In some cases, co-teaching allows blending of university theory and classroom practice by having an individual from each setting participate in the teaching team. In other pairs, it allowed two university faculty members, often from different departments, with diverse viewpoints and styles to share the instruction, providing a rich experience for preservice teachers. Results from this study indicate that students have very positive feedback about their experiences in university co-taught classrooms. Most benefits identified by students were directly related to the instruction and use of class time. Students cited having two different knowledge bases resulting from the diversity of experiences as the greatest benefit of co-teaching. Regardless of the make up of the co-teaching team, students appreciated and benefited from the diverse backgrounds brought to the class. Co-teaching forced students to examine ideas from multiple perspectives and engaged them in varied opportunities to use their critical thinking skills. Many students identified the collaborative nature of a co-taught classroom as an environment that enhanced classroom discussion and encouraged greater student participation. For many students, having a lower student-to-teacher ratio and increased availability of instructors was also beneficial. The development of community and being part of a positive learning environment were added benefits to a co-taught classroom.

Initially, concerns expressed by the students included confusion about which instructor to approach regarding problems or questions. This issue is now shared as part of the faculty co-teaching workshop. After processing student feedback with faculty, co-teaching pairs were encouraged to make more intentional efforts to 'make the invisible visible' by explicitly discussing their modeling of collaborative problem solving. As this began to happen in co-taught courses the feedback also began to shift and there has been a marked decrease of 'confusion' being cited as a drawback.

I also like it when they disagree which helps with the reality of the class. -Teacher Candidate

A second drawback noted by students focused on grading. This concern was also shared with faculty and as a result co-teaching pairs were asked to make more of an overt statement regarding policies and procedures about their grading and review of work in the course. In one of the co-taught classes, the faculty independently and blindly co-graded assignments, eliminating this concern completely.

An additional observation by students was the inequitable division of instructional time. The vast majority of these comments came from students who had prior coursework with one of the faculty members of the coteaching team. Students tended to express dissatisfaction with instructional equity when the unfamiliar instructor assumed the lead role. There were two isolated instances when the inequitable division of instructional time was perceived as a gender/ethnicity issue rather than a result of purposefully co-planned instructional delivery. Our workshop now promotes the importance of shared leadership in planning and teaching.

As we have gradually enhanced our co-teaching workshop for faculty, we have found that student responses have begun to shift away from the confusing nature of co-teaching to a focus on the sense of community fostered in co-taught classrooms. We continue to refine the faculty workshop to enhance the quality of the coteaching experience for all involved.

According to the data collected, co-teaching not only benefited co-teaching candidates but also had positive impacts on the co-teaching faculty. Faculty unanimously report having had an enriching experience in which they learned new material and instructional strategies. The experience of sharing the planning and teaching with a colleague allowed them to utilize different teaching strategies along with expanding their knowledge base about the subject. The co-teaching pairs also felt they became more reflective about their teaching since decisions about how and what to teach had to be negotiated rather than prescribed by one individual. The teams reported that the coteaching experience helped them to improve their teaching and that they enjoyed the time spent discussing their work. The co-teaching experience provided an energizing opportunity for faculty to renew their passion for their profession. 
The overwhelmingly positive nature of the data collected motivates us to continue to find ways to provide opportunities for co-teaching at the university level. The use of co-teaching in teacher preparation is a promising practice for fostering collaborative skills, increasing student participation, and improving classroom instruction and professional growth for all participants.

\section{ACKNOWLEGEMENTS}

Funded by a teacher quality enhancement partnership grant from the U.S. Department Of Education.

\section{REFERENCES}

1. Bacharach, N., Heck, T., \& Dank, M. (2003). Co-teaching: A partnership in the classroom. Paper presented at the annual meeting of the Association of Teacher Educators, Jacksonville, FL.

2. Barbus, S., Tuttle, D., \& Prime, K. (1995). Educating teachers for diverse inclusive schools: A fieldbased university-school partnership. Paper presented at the annual meeting of the Council for Exceptional Children, Teacher Education Division, Honolulu, HI.

3. Bawens, J. \& Hourcade, J. (1995). Cooperative Teaching: Rebuilding the schoolhouse for all students. Austin, Texas: PrEdo.

4. Blanton, L, \& Nowacek, E. (1995). Merging general and special education teacher preparation: How we started and how we made it work. Paper presented at the annual meeting of the Council for Exceptional Children, Teacher Education Division, Honolulu, HI.

5. Cook, L., \& Friend, M. (1995). Co-teaching: Guidelines for Creating Effective Practices. Focus on Exceptional Children (26). 3.

6. Friend, M, \& Cook, L. (1996). Interactions: Collaboration skills for school professionals. White Plains: Longman Publishers.

7. Greogorc, A. (2004). Gregorc Style Delineator ( $3^{\text {rd }}$ Ed). Columbia, CT: Greorc Associates, Inc.

8. Meyers, L., \& Biklen, D. (1992). Inclusive elementary and special education teacher preparation program. Syracuse, NY: Syracuse University, Division for the Study of Teaching and Division of Special Education and Rehabilitation.

9. Platt, J., Walker-Knight, D. Lee, T. \& Hewitt, R. (2001). Shaping future teacher education practices through collaboration and co-teaching. Paper presented at the annual meeting of the American Association for Colleges of Teacher Education.

10. Vaughn, S., Schumm, J. \& Arguelle, M. (1997). The ABCDEs of co-teaching. Teaching Exceptional Children, 30.

11. Villa, R., Thousand, J. \& Nevin, A. (2004). A Guide to Co-teaching: Practical tips for facilitating student learning. Thousand Oaks, CA: Corwin Press.

12. Wenzlaff, T., Berak, L., Wieseman, K., Monroe-Baillargeon, A., Bacharach, N., \& Bradfield-Kreider, P., (2002). Walking our talk as educators: Teaming as a best practice. In E. Guyton \& J, Ranier (Eds). Research on Meeting and Using Standards in the Preparation of Teachers. (pp.11-24). Dubuque, IA: Kendall-Hunt Publishing.

13. York-Barr, J., Bacharach, N., Salk, J. Frank, J. and Beniek, B. (2004). Team Teaching in Teacher Education: General and Special Education Faculty Experiences and Perspectives. Issues in Teacher Education, 13, 73-94. 